\title{
Three Traps with Bait for Insects
}

\author{
M. N. Tsurikov \\ Voronezh State University, Galich'ya Gora Nature Reserve, Lipetsk oblast, 399240 Russia; \\ e-mail:vgu@zabonski.lipetsk.ru \\ Received June 22, 2004
}

\begin{abstract}
Three traps with bait for coprophagous and necrophagous insects and the mole cricket, a polyphagous pest, are described. Due to their design, the traps strengthen the bait odor, prolong their service life, and prevent coprophages and necrophages from mixing with bait, which markedly facilitates insect collection.
\end{abstract}

DOI: $10.1134 / \mathrm{S} 0013873806010088$

A number of traps for invertebrates based on the use of attractants are described in the literature. They include universal devices such as the Zhuravskii apparatus (Yakobson, 1905), a fly trap (Shcherbakov, 1953), a trap for collecting necrophagous and coprophagous insects (Lumaret, 1979), and a trap with an attractant for insects (Tsurikov and Tsurikov, 2001), in which different kinds of bait may be used to attract invertebrates. Specialized traps are known that are baited with dead animals (Palii, 1966; Shubeck, 1976, 1984; Aiken, Roughley, 1985; etc.), plants (Bramson, 1896; Stark, 1936; Fasulati, 1971; etc.), or bodily wastes, including dung and feces (Bernon, 1980; Houston et al., 1982; etc.).
The traps described in this paper have some design features that strengthen the odor of bait and extend their service life. In addition, they prevent coprophages and 1 necrophages from mixing with bait, which facilitates insect collection.

\section{Soil Trap with Bait}

The soil trap with bait is designed mainly for collecting coprophagous and necrophagous insects. The trap (Figs. 1a, 1b) consists of (1) a cylindrical container $150 \mathrm{~mm}$ in height, (2) a smaller cylindrical container (80 $\mathrm{mm}$ high), (3) a rod $1 \mathrm{~mm}$ in diameter, and (4) 1$\mathrm{mm}$ wire mesh. The internal diameter of container 1 (a)

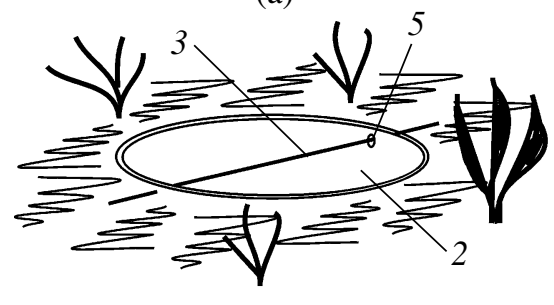

(c)

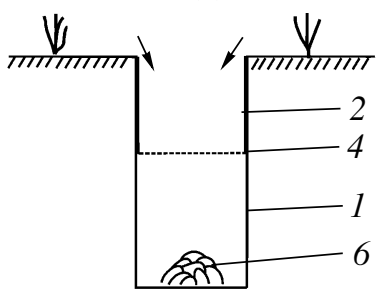

(b)

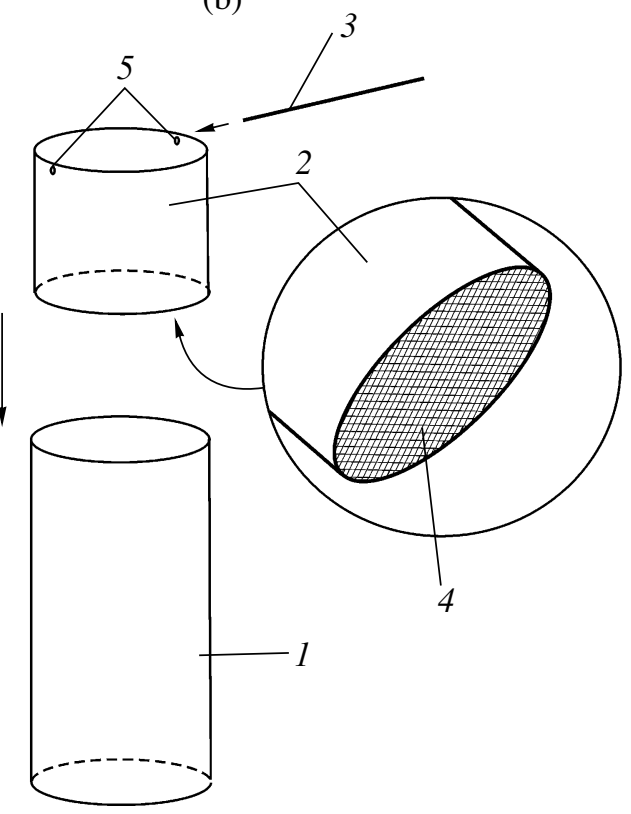

Fig. 1. Soil trap with bait: (a) installed trap, general view from above; (b) its components; and (c) longitudinal cross section: (1) larger cylindrical container, (2) smaller cylindrical container, (3) rod, (4) wire mesh, (5) holes for the rod. 

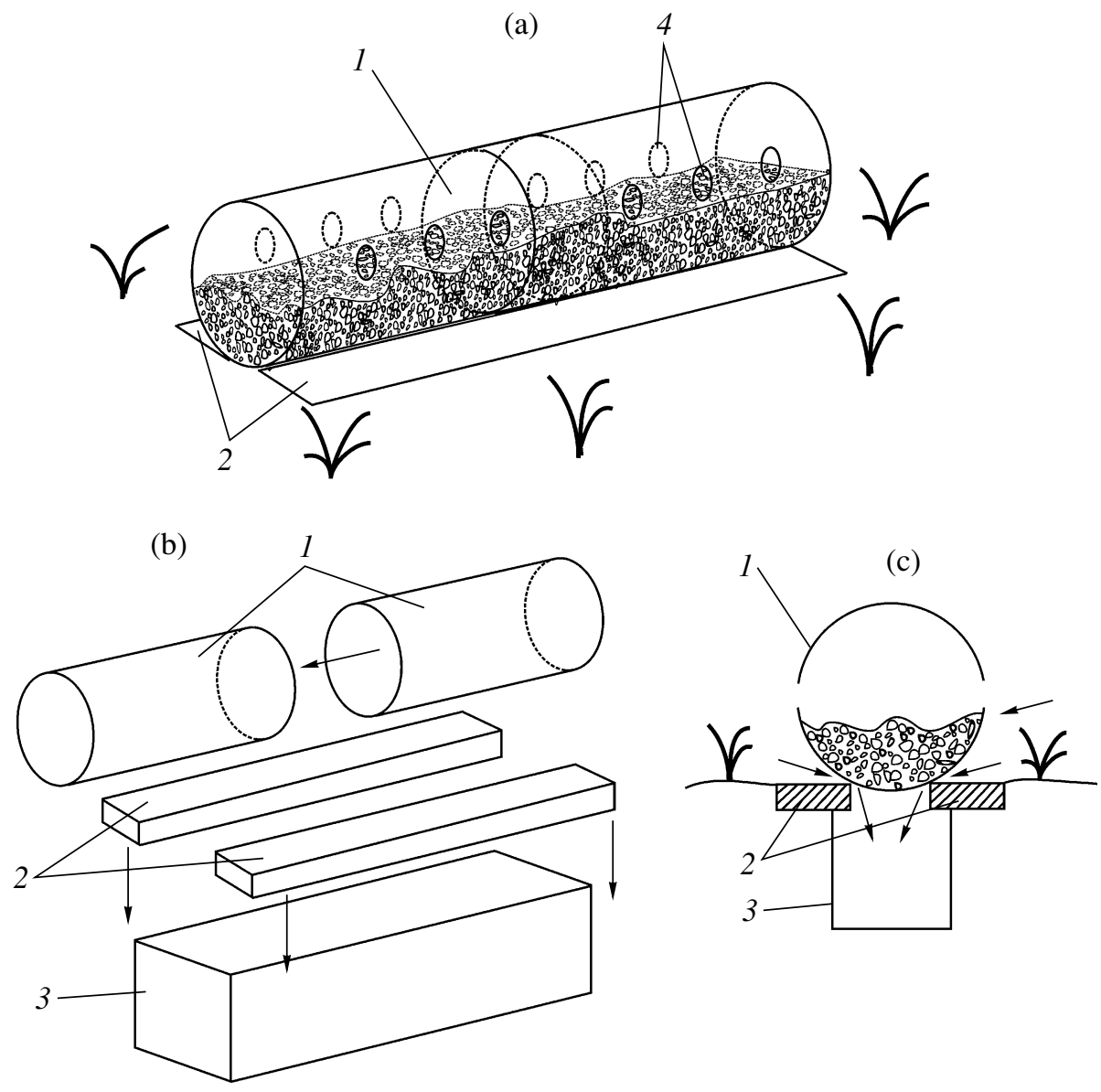

Fig. 2. Trap for necrophages and coprophages: (a) installed trap, general view; (b) its components; and (c) cross section: ( 1 ) container, (2) polyurethane foam plates, (3) catching trough, (4) holes in the container.

should be 1-2 mm greater than the external diameter of container 2, as the latter must easily fit inside container 1. The bottom of container 2 is covered with wire mesh, and two holes $2 \mathrm{~mm}$ in diameter (5) are made at a distance of $2 \mathrm{~mm}$ from its upper edge, as shown in Fig. $1 \mathrm{~b}$. The rod (3) should be $20 \mathrm{~mm}$ longer than the diameter of container 1 .

The trap is installed and operates as follows. A hole $150 \mathrm{~mm}$ deep with a diameter equal to that of container 1 is dug into the soil. Bait (Fig. 1c, 6) is placed on the bottom of container 1, the rod (3) is put through the holes in the wall of container 2 , and this container is inserted into container 1 . The assembled trap is installed so that the rod holds its edge level with the soil surface. Invertebrates attracted by the odor of the bait come to the trap and fall into container 2 (Fig. 1c). This design of the trap does not allow insects to come into contact with the bait. Hence, the bait remains functional for a longer time (it is not consumed by animals), and the material is easier to collect from the trap, as invertebrates do not mix with the bait). Another advantage of the trap is that the objects of study (in the case of necrophages) present no hazard to human health.
Trap for Necrophages and Coprophages

1

The trap (Figs. 2a, 2b) consists of (1) a container made of two cylindrical parts of 2-1 plastic bottles, (2) two polyurethane foam plates (parallelepipeds $300 \times 50 \times 20 \mathrm{~mm}$ in size), and (3) a rectangular metal or plastic catching trough $(300 \times 80 \times 100 \mathrm{~mm})$. The trough is dug into the soil so that its edges are $20 \mathrm{~mm}$ below the soil surface (Fig. 2b). The foam plates are placed along the trough edges so as to extend over them by $10 \mathrm{~mm}$, with their surface being level with the soil surface. To this end, special depressions in the soil should be made. It is also necessary to cut about 12 holes $15 \mathrm{~mm}$ in diameter (Fig. 2a, 4) along the opposite sides of the container.

The trap operates as follows (Fig. 2c). The two halves of the container are used as a scoop to collect a portion of fresh manure or a dead animal and then are connected by inserting one half into the other. The container with bait $(1)$ is placed horizontally above the trough (3). Beetles attracted by the odor emanating from numerous holes (4) approach the container and, trying to penetrate under it, easily depress the soft edge of the foam plate (2) and fall into the trough. 


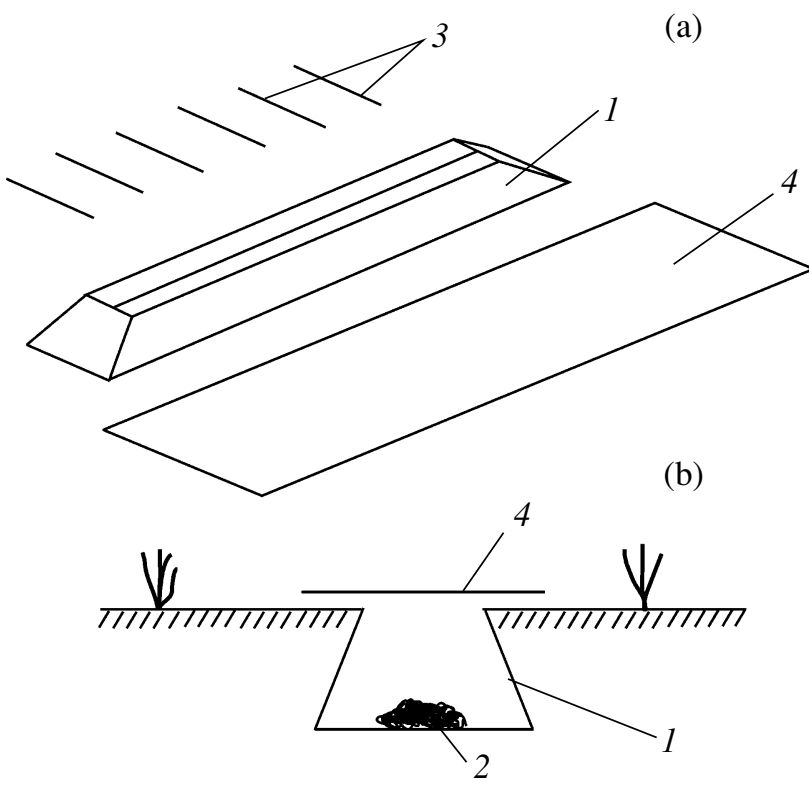

Fig. 3. Trap for mole crickets, (a) components and (b) lateral cross section: (1) trough, (2) bait, (3) rods.

\section{Trap for Mole Crickets}

The main part of the trap (Figs. 3a, 3b) is a metal trough (1) $200 \mathrm{~mm}$ high that narrows from $500 \times 200$ $\mathrm{mm}$ at the base to $400 \times 100 \mathrm{~mm}$ at the top. The trough with bait, such as boiled corn (2), is dug into the soil so that its upper edge is level with the soil surface. Several rods (sticks) $10 \mathrm{~mm}$ in diameter (3) are placed across the opening, and the trap is covered with a $1000 \times 400$ $\mathrm{mm}$ sheet of roofing paper (4). Thus, a gap is left between the trough and its cover. As the roofing paper is heated by the sun, the trough with the bait is heated as well, which intensifies the odor propagating through this gap. Mole crickets attracted by the odor move toward bait and fall into the trough. To make bait more attractive, some water may be poured into the trough.

\section{REFERENCES}

1. R. B. Aiken and R. E. Roughley, "An Effective Trapping and Marking Method for Aquatic Beetles," Proc. Acad. Nat. Sci. Phila. 137, 5-7 (1985).

2. G. Bernon, "A Trap for Monitoring Coleoptera and Phoretic Mites Associated with Dung," Coleopterists Bull. 34 (4), 389-391 (1982).

3. K. L. Bramson, Practical Entomology: Pests and Methods of Their Control, 2nd. ed. (Yekaterinoslav, 1896), vol. 2 [in Russian].

4. K. K. Fasulati, Field Studies on Land Invertebrates (Vysshaya Shkola, Moscow, 1971) [in Russian].

5. W. W. K. Houston, J. E. Feehan, and S. Runko, "Methods for Harvesting Large Numbers of Dung Beetles (Coleoptera: Scarabaeidae)," J. Austral. Entomol. Soc. 21 (3), 217-219 (1982).

6. I. P. Lumaret, Un piége attractif pour la capture des insectes Coprophages et Nécrophages, Entomologgiste 1 35 (2), 63-66 (1979)

7. V. F. Palii, Methods of Studies on the Fauna and Phenology of Insects (Tsentr.-Chernozemnoe Knizh. Izd., Voronezh, 1970) [in Russian].

8. B. S. Shcherbakov, Insects as an Object of School Work (Uchpedgiz, Moscow, 1953) [in Russian].

9. P. P. Shubeck, "An Alternative to Pitfall Traps in Carrion Beetle Studies (Coleoptera)," Entomol. News 87 (5-6), 176-178 (1976).

10. P. P. Shubeck, "An Inexpensive Carrion Beetle Trap (Coleoptera: Silphidae)," Entomol. News 95 (2), 63-64 (1984).

11. V. N. Stark, Guidelines for Collecting and Studying Bark Beetles (Leningrad, 1936), Issue 20 [in Russian].

12. M. N. Tsurikov and S. N. Tsurikov, "Nature-Friendly Methods for Studying Invertebrates in Russian Reserves," Tr. Assots. Osobo Okhranyaemykh Prirodnykh Territorii Tsentral'nogo Chernozem'ya Rossii, no. 4 (2001).

13. G. G. Yakobson, Beetles of Russia and Western Europe (Izd. A. F. Devriena, St. Petersburg, 1905) [in Russian].

SPELL: 1. coprophages 